\title{
Carl Schmitt's Morphology: From Political Theology to Aesthetics
}

\begin{abstract}
The aim of this chapter is to analyze Carl Schmitt's morphology starting with his studies on Roman Catholicism as a perfect political form. The possibility of a morphology of Schmitt's theories of law and the State is often ignored, but Walter Benjamin and Jacob Taubes grasped the centrality of the form in Schmittian philosophy within its political engagement. My thesis is that they suggested an alternative idea of form without settling for a formal dissolution. To deconstruct the formal structure of Western power it is no more satisfactory. The power of gestalt-zerstörend - as Taubes defined it - must be complemented by a forming power, like a narrative capable of addressing the alluring side of political theology.
\end{abstract}

\section{Introduction. The Form as a Political Engagement}

The possibility of a morphology of Schmitt's theories of law and the State is often ignored (Burger 1986; Levi 2007; Pan 2017) but I think that the development of a morphological analysis of these theories can cast light on the multifarious features of the Political that lie at the heart of Schmitt's thought and its lasting influence.

According to Schmitt, the Roman Catholic Church represents the perfect political form because it encompasses a particular idea of representation, one which emphasizes the close link between religion and politics. From this perspective Schmitt's work is appraised, here, in terms of the theological-political structure of the form as it would subsequently be developed in the works of Romano Guardini and Hans Urs von Balthasar (Guardini 1923; Balthasar 1961-69, Bd. 1; Balthasar 1970; Martin 1925-26; Esposito 1988; Bröckling 1993; Taubes 1993; Lönne 1994).

In a contrastive parallel, the crucial role played by the idea of form in the Schmittian paradigm emerges also in his appraisal of Romanticism, where he points to the peculiar inability of the Romantic movement to shape the historical process. Thus, according to Schmitt, while Roman Catholicism represents the perfect political form, a singular failure of Romanticism consists in the vagueness of its forms in art as well as in politics.

Ә OpenAccess. ( 2021 Francesca Monateri, published by De Gruyter. (cc))BY-NC-ND This work is licensed under the Creative Commons Attribution-NonCommercial-NoDerivatives 4.0 International License. 
In Schmitt's analysis it is thus the form that contrasts Roman Catholicism with Romanticism: the Church becomes the most political of institutions, whereas Romanticism tends to be seen as the essence of the unpolitical.

This reading of Schmitt's theories makes it possible to underline the centrality of form and aesthetics in his paradigm. Indeed, the pivotal role played by aesthetics in the development of Schmitt's theories is an underrated factor, and a full morphological consideration of the premises of his paradigm would lead to a complete reversal of roles in terms of the background and foreground in Schmittian studies.

My aim, here, is to focus on Schmitt's works on Catholicism and Romanticism in order to disclose how they preempt and establish his main argument on das Politische, 'the Political'. In these terms, it becomes possible to prove the aesthetic genesis of Schmitt's political theory through his studies on the political form. As we shall see, even the main Schmittian feature of 'the Political' as the decision between friend and enemy - must be appraised through the author's own reference to the aesthetic opposition between beautiful and ugly. An analogy by which Schmitt means to show the existence of a structural connection between aesthetics and political science. It is of special relevance to the aesthetic-political link that Schmitt invites us to read this distinction starting with Däubler's expression “der Feind ist unsre eigne Frage als Gestalt” (Däubler 1916, 58).

The first part of this chapter aims at reconstructing a Schmittian morphology in order to disclose the 'aesthetic matrix' of his understanding of the political (Schmitt 1916). Subsequently, I confront the critique of this depiction as it is grounded in the dialogue between Carl Schmitt, Walter Benjamin and Jacob Taubes. Within this frame, my conclusion is that a full political critique of Schmitt's theories needs to go through a morphological reconstruction of their premises.

Aesthetics has always had political implications, but we only through morphology can we fully understand them. The question at issue here is not the reconstruction of a theory of political forms as happened in classical antiquity, but the rethinking of a politics of forms, as a morphology of power, grounded in a dynamic form able to assume time and history within itself. This is possible firstly by reconstructing Schmittian morphology, and afterwards by developing the critique provided by Walter Benjamin and Jacob Taubes.

Political theology is the hidden core of this matter - the only key to seeing this discussion clearly - since it has been understood as a symbolic structuring of the historical present, and ultimately, as a form. In these terms political theology becomes a tool to disclose politics' aesthetic matrix. This appears to be the only way to safeguard a secularized form of transcendence when bare imma- 
nence is evidently untenable. Indeed, my aim is to ask where the mythopoetic resource that political theology now seems unable to preserve should be placed.

\section{Carl Schmitt's politics of forms}

As we saw in the introduction, a morphological evaluation of the Schmittian paradigm has to start primarily with two of his works: Politische Romantik (1919), a critique of political romanticism, and Römischer Katholizismus und politische Form (1923), an essay on Roman Catholicism. In both, Schmitt discusses his own concept of form (Schmitt 1998; Schmitt 2016).

Starting with his studies on Romanticism, it is especially relevant that Schmitt's reconstruction of the Romantic era is centered solely on the second generation of Romanticism: a tendentious reconstruction which has a functional role in Schmitt's thought and which must be read as a criticism of the Weimar Republic (McCormick 2011). However, Politische Romantik represents a starting point in getting closer to the question of form in Schmitt's early works. The essay is a critique of Liberalism via a critique of the Romantic idea of form. Indeed, Schmitt's appraisal of Romanticism is a political critique which passes through a morphological one. In other words, Political Romanticism turns out to be unpolitical due to its failure to elaborate any idea of form. Here Romanticism appears unable to develop a "große Form" that might also be politically influential.

Eine Zeit, die aus ihren eigenen Voraussetzungen keine große Form und keine Repräsentation hervorbringt, muss solchen Stimmungen erliegen und alles Formale und Offizielle für einen Betrug halten. Denn keine Zeit lebt ohne Form, mag sie sich noch so ökonomisch gebärden. Gelingt es ihr nicht, die eigene Form zu finden, so greift sie nach tausend Surrogaten aus den echten Formen anderer Zeiten und anderer Völker, um doch das Surrogat sofort wieder als unecht zu verwerfen (Schmitt 1998, 16).

However, the same charge may be levelled against Carl Schmitt, thus saving Romanticism's depiction of form. Indeed, as the Romantic heritage passes down, the crisis of modernity lies in the relationship between form and time, two concepts that are only apparently at odds with each other: on the one hand, the stability of the form and, on the other, the dynamic movement of time. For the Romantics, in fact, they are perfectly integrated. In other words, when the stable form of classicism loses its strength, the absence of forms becomes unsustainable and the Romantics have to invent a form suitable for modernity: the Novel. According to the Romantics, the Novel alone proves to be the form for their time - as Schlegel's tautology shows (Schlegel 1969). The Novel is a form that 
withholds historical time, and that is how this literary form - considered the last of the literary genres in antiquity - became the prominent one of the modern era (Vercellone 1998).

Schmitt, for his part, is unable to conceive a similar form. It is precisely the problem of the relationship between form and time that Schmitt is unable to solve (Schmitt 1956). Therefore, in contrast to the Romantics' dynamic form, Schmitt develops an idea of form which must be read in the larger context of his Decisionism (Marder 2014). Decisionism is the only form that Schmitt provides for his own era, revealing the original implication between aesthetics and politics. However, here form prevails against time and its results are inflexible and conservative.

Schmitt's Decisionism is grounded in the idea of representation elaborated in Römischer Katholizismus. Thus, the unpolitical side of Romanticism is structurally opposed to the political commitment of Roman Catholicism drawn up by Schmitt in 1923. In Römischer Katholizismus und politische Form, Schmitt insists on analyzing Catholicism from a political point of view since the political idea of the Catholic Church lies in "Formalen Überlegenheit” (Schmitt 2019, 14). From this perspective, it is the idea of form which sets Roman Catholicism against Political Romanticism so radically that there cannot be a Romantic who is also a Catholic: "Aber als sie auch innerlich von ihm überwältigt wurden und im Ernst fromme Katholiken sein wollten, mussten sie ihren Subjektivismus aufgeben” (Schmitt 1925, 58).

According to Schmitt, Catholicism's ability to produce a form for the present era is grounded on "der strengen Durchführung des Prinzips der Repräsentation” (Schmitt 2019, 14): that is, the Church is the keeper of the political form because it possesses the power of representation.

Diese Welt [der Welt des Repräsentativen] hat ihre Hierarchie der Werte und ihre Humanität. In Ihr lebt die politische Idee des Katholizismus und seine Kraft zu der dreifach großen Form: zur ästhetischen Form des Künstlerischen, zur juridischen Rechtsform und endlich zu dem ruhmvollen Glanz einer weltgeschichtlichen Machtform. (Schmitt 2019, 36)

In these terms, there are three kinds of forms unified by Catholicism: the aesthetic form of art, the juridical form of law and form as a world-historical power. However, it is the aesthetic beauty of the form that is the key element of Catholicism, as stated by Schmitt: “die ästhetische Schönheit der Form” (Schmitt 2019, 37). This is true in the whole history of Roman Catholicism. Therefore, as I said, Schmitt's analysis of form must be considered as just one declination of the relationship between Roman Catholicism and aesthetics. It is, for example, Balthasar who clarifies that the theory of form - understood as a legitimization 
of the political structures of this world - begins with Catholicism which builds a Church out of the resurrection of Christ, a permanent worldly structure grounded in the aesthetic idea of beauty. Balthasar writes that Christ's death pours its beauty into the Catholic Church and introduces the idea of political forms where the Church's power is legitimized in this passing world (Balthasar 1961-69, Bd. 1). The consequence is the development of an idea of forms capable of legitimizing power.

In both Balthasar and Schmitt there is a distinction between the art form and the aesthetic form. In other words, the artistic form - die Form des Künstlerischen - does not correspond to the aesthetic beauty of the form - die ästhetische Schönheit der Form - but is only one of its possible variations. Indeed, the aesthetic form of Catholicism, in Schmitt's words, holds within itself all three forms: of art, of law, and of history. Therefore, in Schmittian depiction, it is possible to identify two notions of aesthetics: aesthetics as a philosophy of art and aesthetics as a theory of beauty which, nevertheless, has always been politically declined for its formal appeal. Aesthetics - we could say - as a morphology, shows the original permeation between form and politics. Indeed, the aesthetic triumph of Catholicism does not consist in the trappings of a magnificent procession “den äußeren Prunk einer schonen Prozession" - or in the great architectures - “die Große Architektur” - but exclusively in its ability to form - “der Fähigkeit zu der Form” (Schmitt 2019, 38).

Starting from this conception of the form, Schmitt elaborates a particular idea of representation - as Repräsentation - contrasting the Vertretung of politics in his time. Once more - as in Politische Romantik - Schmitt focuses on the critique of the idea of representation implied in liberalism and, once more, his political critique passes through an aesthetic one.

\footnotetext{
Man kann beobachten, wie mit der Ausbreitung des ökonomischen Denkens auch das Verständnis für jede Art Repräsentation schwindet. Doch enthalt der heutige Parlamentarismus wenigstens nach seiner ideellen und theoretischen Grundlage den Gedanken der Repräsentation. Er beruht sogar auf dem mit einem technischen Ausdruck so genannten Repräsentativprinzip. Soweit darin nichts ausgesprochen ist als die Bezeichnung einer Vertretung, nämlich der wählenden Individuen, wurde es nichts Charakteristisches bedeuten. (Schmitt 2019, 42-43)
}

The only way that Schmitt contrasts the absence of representation is through political decisionism, but it also represents a tragic option for his theory.

Indeed, precisely with political decisionism Schmitt highlights a need to create order through decision. In this way, the non-existence of a primordial, essential, already given form also emerges, though it is still possible to create it, to provide it. It is the decision that creates the form, without it the form does not 
exist. This kind of form thus denounces that order is actually an artificial creation. It is precisely from this Schmittian idea of form that Karl Löwith moves ahead with claims of a close bond between Schmitt's political theory and German Romanticism (Löwith 1935). This is true if we consider the inability of decisionism to provide a dynamic form - just like Schmitt's interpretation of the Romantic Era - however, German Romanticism tried to provide a different idea of form, as I have tried to demonstrate. Finally, Schmitt's essays on German Romanticism and Roman Catholicism represent the prelude to political theology conceived as a form for modernity, a conservative form devoted only to the preservation of the past that is unable to preserve the Romantic heritage.

\section{Carl Schmitt and Walter Benjamin. A Romantic Morphology}

Schmitt's relationships with Jewish intellectuals - such as Walter Benjamin and Jacob Taubes - are well known ${ }^{1}$. Throughout Taubes' visits to Schmitt, as well as in their intense correspondence, some possible readings of Walter Benjamin's works can also be found. Indeed, it is precisely Taubes who reproaches Gershom Scholem for having tried to hide Benjamin's esteem for Carl Schmitt. And of course, Benjamin and Taubes are two Jewish readers of Schmittian thought. But here what we are particularly interested in is how Benjamin and Taubes understand Schmitt's morphology in their interpretation of his works.

My aim is to prove that they provided a criticism of Schmittian morphology that suggested an alternative idea of form without settling for a formal dissolution. Furthermore, both pass specifically through a refusal of the form implied in Roman Catholicism, to advocate a German Romantic renewal. Thus, Benjamin and Taubes grasped not only the centrality of the form in Schmittian philosophy, but also its political commitment.

1 Taubes narrates his two meetings with Carl Schmitt (Taubes 1993). They also have an intense correspondence (Schmitt - Taubes 2012). Benjamin, for his part, wrote twice that he was influenced by Carl Schmitt. The first time was in a curriculum vitae dated 1928, the second in a letter written to Schmitt in December 1930 (Benjamin 2006, 886-887). Schmitt mentions this letter in his 1956 book on Shakespeare (Schmitt 1956). The letter was not published in the first edition of Benjamin's correspondence (Scholem-Adorno 1966), but was later printed by Hans-Dietrich Sander (Sander 1970). Also, Jacob Taubes reproaches Gershom Scholem for denying the existence of the letter both in public conferences and in their private correspondence. (Taubes 1982a; 1982b; 1986). Meanwhile, Horst Bredekamp focused his attention on Benjamin's esteem for Carl Schmitt (Bredekamp 2017). 
The dialogue between Carl Schmitt and Walter Benjamin only apparently shifts the problem of form from the theory of law to the theory of art and it reveals the link between aesthetics and politics ${ }^{2}$. Benjamin explicitly grasps the aesthetic implications of Schmitt's theory of the State and for this reason he turns out to be a fundamental step in understanding Schmittian morphology. It should also be emphasized that even the alternative aesthetic theory that Benjamin provides for Schmitt's morphology is also a political option.

This battle is played out, as I have said, on the relationship between Catholicism and Romanticism, whose positions within their opposition to each other Walter Benjamin reverses to the detriment of the Schmittian perspective.

Benjamin was exposed to the Roman Catholic idea of representation through Stefan George's circle, from which he departs almost immediately (Roberts 1982). Specifically, it is Ludwig Klages' symbolism that impresses him. Benjamin's early works on German Romanticism and Roman Catholicism are signs of his deflection from this belief (Banjamin 1920). For instance, Benjamin's article devoted to Goethe's Die Wahlverwandschaften is an explicit criticism of the so-called chancellor of George's Kreis, Friedrich Gundolf, who also interpreted Goethe's work (Benjamin 1924-5).

These Benjaminian studies are subsumed into the Ursprung des deutschen Trauerspiels. Here, the refutal of Klages' symbolism becomes a critique of a particular idea of representation. In this context, we can grasp the political engagement hidden in the distinction between symbol and allegory (Benjamin 1928). Indeed, the symbol is the true political form of Catholic representation, while the allegory is an alternative form whose origins must be tracked down in German Romanticism.

The Romantic Age has criticized the symbol as being incapable of representing modernity, and, indeed, Benjamin resumes and carries on this tradition. Thus, the symbol becomes not only incapable of a satisfactory representation, but is also the bearer of a violent depiction and the allegory is its true alternative.

Benjamin's allegory is a system of meanings that must be read in a strictly representative way. The allegorical image, far from rejecting any form of representation, promotes a dynamic movement in favor of a renewal of fading forms. The allegory, as a last resort, is a form of a sort and, specifically, it is an alternative to the Roman Catholic one, which is the symbol.

Gleichzeitig mit dem profanen Symbolbegriff des Klassizismus bildet sein spekulatives Gegenstück, der des Allegorischen, sich heraus. Eine eigentliche Lehre von der Allegorie ist

2 "eine Bestätigung meiner kunstphilosophischen Forschungsweisen durch Ihre staatsphilosophischen entnommen habe” (Benjamin 2006, 887). 
zwar damals nicht entstanden noch hatte es sie vordem gegeben. Den neuen Begriff des Allegorischen als spekulativ zu bezeichnen ist aber dadurch gerechtfertigt, dass er in der Tat als der finstere Fond abgestimmt war, gegen den die Welt des Symbols hell sich abheben sollte. Die Allegorie, sowenig wie viele andere Ausdrucksformen, ist durch ,Veralten' nicht schlecht - weg um ihre Bedeutung gekommen. Vielmehr spielt hier wie oft ein Widerstreit (Benjamin 2006, 337).

Whether allegorical perception - in which the image is debris - presents itself as the only aesthetic form capable of representing its own epoch, an alternative political possibility nevertheless exists: an aesthetic and political language that comes out of ruins and that is still capable of representations.

The only viable politics, as the Theologisch politische Fragment shows, is nihilism. Nevertheless, the refusal of the idea of forms does not coincide with the refusal of any political representation (Benjamin 1921). As Jacob Taubes perceives, nothing can be saved from the totalizing symbolic form, though, as I will show, a political possibility remains in the aesthetic form of allegory.

Thus, even if in the Fragment the method of world politics must be called nihilism, in Taubes' reading, this nihilism must be read as the morphe of this world that has passed (Taubes 1993, 100). Building on this, Taubes tries to track down a political proposal in Benjamin's thought. While Carl Schmitt holds the form as an alternative to nihilism, Jacob Taubes is the bearer of an anti-conservative approach aimed at an apocalyptic renewal of the forms of this world. It is precisely in nihilism that exists a chance to save the form, along the lines of Walter Benjamin.

\section{Jacob Taubes and Carl Schmitt. An Apocalyptical Morphology}

Jacob Taubes represents the second fundamental step in understanding that both Schmitt and Benjamin have as their major focus a political morphology. Taubes' criticism of Schmitt's politics comes through his representation of the idea of form: liberation can be attained by fighting against the form as a peculiar obsession of Western eschatology. Thus, in these terms, he retains the centrality of form in Schmitt's theory, but also its necessary bond with politics: Schmitt is criticized as a Jurist according to a conservative interpretation of the Law connected, once more, with the form. It is the Law that withholds the form and the jurists are its keepers. 


\begin{abstract}
Es ist eines, Theologe zu sein, ein zweiter Philosoph, und es ist ein Drittes, Jurist zu sein. Das - habe ich im Leben erfahren - ist eine ganz andere Weise, die Welt zu begreifen. Der Jurist muss die Welt, wie sie ist, legitimieren. Das liegt in der ganzen Ausbildung, in der ganzen Vorstellung des Amtes des Juristen. Er ist ein Clerk, und er versteht seine Aufgabe nicht darin, Recht zu setzen, sondern Recht zu interpretieren. Das Interesse von Schmitt war nur eines: dass die Partei, dass das Chaos nicht nach oben kommt, dass Staat bleibt. Um welchen Preis auch immer. Das ist für Theologen und Philosophen schwer nachzuvollziehen; für den Juristen aber gilt: solange auch nur eine juristische Form gefunden werden kann, mit welcher Spitzfindigkeit auch immer, ist es unbedingt zu tun, denn sonst regiert das Chaos (Taubes 1993, 139).
\end{abstract}

Taubes' refusal of the political form transpires, once more, through a critique of Roman Catholic submission to the power of this world (Løland 2020). Indeed, it is Schmitt - in Taubes' depiction - that grasps the political value of the Roman Church through the Christian idea of the katechon, evoked by Paul in the Second Letter to the Thessalonians. An image which alludes to the restraining force which keeps this world and delays the Second Coming, yet which has become conceptually intermixed with a symbolic and figurative legitimation of political power.

In these terms, Taubes writes that the idea of katechon - which catches Carl Schmitt's attention - is the first instance in the Christian experience of the end of times being subdued. In these terms, Roman Catholicism hands eschatology over to the power governing this world (Taubes 1993, 139). In Taubes' eyes, the katechon has tamed the Endzeit idea of early Christian communities, thus grounding the Roman Church.

\begin{abstract}
Das ist das, was er später das Kat-echon nennt: Der Aufhalter, der das Chaos, das von unten drängt, niederhält. Das ist nicht meine Weltanschauung, das ist nicht meine Erfahrung. Ich kann mir vorstellen als Apokalyptiker: soll sie zugrunde gehn. I have no spiritual investment in the world as it is. Aber ich verstehe, dass ein anderer in diese Welt investiert und in der Apokalypse, in welcher Form auch immer, die Gegnerschaft sieht und alles tut, um das unterjocht und unterdruckt zu halten, weil von dort her Kräfte loskommen können, die zu bewältigen wir nicht in der Lage sind (Taubes 1993, 139).
\end{abstract}

Once more, the alternative to Catholic representation must be located in early Romanticism. It is through Lessing's writings that Taubes regains a modern form of Millenarianism: the religious and political belief in a radical transformation of the whole of society. According to Taubes, philosophical Millenarianism has an anarchic vocation and Lessing seems to get closer to this perspective when he declares: people will only be governed well when they no longer need a government. 
Der philosophische Chiliasmus ist anarchisch, und von Lessing wird der lebhafteste Widerwille gegen „das Lächerliche und Unseligmachende aller moralischen und politischen Maschinerien“ berichtet. In einer Unterredung kommt Lessing einmal so sehr in Eifer, dass er behauptet, die gesamte „,ürgerliche Gesellschaft müsse noch ganz aufgehoben werden, und so toll wie es klingt, so nah ist es dennoch der Wahrheit. Die Menschen werden erst dann gut regiert werden, wenn sie keiner Regierung mehr bedürfen“ (Taubes 2007, 181).

Yet, this will be realized when the Kingdom of God comes to Earth. The struggle against the katechon, presented in Lessing's thought, has a revolutionary political engagement. In other words, Jacob Taubes criticized Schmitt as a conservative, only interested in the preservation of the formal order of this passing world. On the other hand, in Jacob Taubes lies a formal alternative to the Schmittian idea. Thus, he represents the morpho-political reversal of Schmitt's aesthetics of political forms: he dedicates the beginning of Abendländische Eschatologie to the idea of revolution by emphasizing that even revolution has its forms and is "formalized", particularly when it shatters the rigid structures of the positivity of the world. By these theorists of messianism the apocalypse is never a reaffirmation of obscurity. Taubes writes in this regard that the apocalyptic principle combines within it a power that is both form-destroying [gestalt-zerstörend] and forming [gestaltend].

Das telos der Revolution bindet die chaotischen Gewalten, die sonst alle Formen sprengen und die gesetzten Grenzen überschreiten würden. Auch Revolution hat ihre Formen und ist „in Form“, gerade wenn sie erstarrte Formen, die Positivitäten der Welt, erschüttert. Das apokalyptische Prinzip enthält in sich eine gestalt-zerstörende und eine gestaltende Macht vereinigt (Taubes 2007, 20).

In actual fact, there are two powers summed up by the revolutionary movement: one which destroys the ancient forms and another which forges newer forms. The constitutive movement of the apocalypse is, in these terms, a destruction paving the way for a creation. These two authors - Benjamin and Taubes - contest the Schmittian idea of political form, yet neither of them comes to a total refusal of form. Although Schmitt's depiction is not satisfactory - starting with his studies on Roman Catholicism - it does not correspond to the abandoning of every form. Jacob Taubes, like Walter Benjamin, opts for the form, but an alternative one. Schmitt's conservative form is Decisionism, Benjamin's alternative proposal lies in the allegorical representation and, finally, Taubes' stress is on the importance of a forming power for the revolution. Here, it is evident that the form is both an aesthetic and a political commitment. In this way eschatology may challenge our political categories through an alternative morphological production poised to invalidate our current theories of political legitimacy. 


\section{Conclusions. From Political Theology to Aesthetics}

A device that clearly marks the relationship between Carl Schmitt on the one hand, and Walter Benjamin and Jacob Taubes on the other, is a chiasmus. While according to Schmitt the opposition between Catholicism and Romanticism involves a political commitment of the former and an unpolitical commitment of the latter, for Benjamin and Taubes this link is reversed.

For them, Romanticism has a political significance in suggesting an alternative idea of form. Roman Catholicism, instead, turns out to be unpolitical: according to Benjamin, the symbolic form is incapable of any kind of representation, while Taubes' understanding of the Roman Catholic Church stresses the loss of the political significance of Jewish messianism. In this split between Romanticism and Catholicism, peculiarly opposed in this chiasmus, political theology leaps out as a legitimation system of a historical period.

Nowadays, the revival of political theology as a tool for analyzing the contemporary age leads to doubt about its relevance ${ }^{3}$. Our current appraisal of political theology passes through the relevant philosophical developments that not only Carl Schmitt but also Jan Assmann attached to it. They provided two opposite models of political theology. Schmitt claimed that all concepts of modern political thought are secularized theological concepts, while Assmann stressed the theologization of political content (Asmann 2000). However, political theology always seems to be a way to guarantee a legitimation of historical time.

The main critique to Schmittian theorization is provided by Peterson who discussed the possibility of a political theology as a Christian mold (Peterson 1935). In the Schmittian perspective, rejecting the existence of political theology means, however, arguing the impossibility of legitimizing modernity. In these terms, it seems necessary to reconstruct political theology from the relationship

3 On this point the Italian debate generated by Tronti's studies in the 1970s is particularly important. While Giorgio Agamben - re-thinking Benjamin's intuitions - searches for an economy of salvation in order to derive the modern theory of democracy from theology, Massimo Cacciari focuses his legitimation of contemporary politics on the theological concept of katechon, as a necessary ordering force which must in the meantime hold firmly against the impending chaos between the First and the Second Coming. Finally, Roberto Esposito emphasizes his view on creating an end to political theology. According to Esposito our era faces the return of the removed, represented by the silent penetration of a theological-political conception, which is addressed in both Negri's paradigm as an eschatological declination of political theology, and in Agamben's messianic perspective. (Agamben 2007; Cacciari 2013; Stimilli 2019; Esposito 2020). 
between Hans Blumenberg and Carl Schmitt. They both had as a purpose the formal organization of their own contemporary world, with two opposite juridical concepts: legitimacy and secularization (Blumenberg 1973). In actual fact, only morphology can grasp their formal commitment.

My thesis is that Schmitt's understanding of political theology must be read in parallel with his conception of the political form, in the larger context of his renewal of Roman Catholicism. In this outline on Schmitt, political theology explicitly assumes an aesthetic connotation that appears as a force withholding the form: a symbolic structuring of the historical present. In other words, political theology gives shape to the world political order and, above all, to the world symbolic order, fighting against the aggression of a formless nihilism.

Thus, while Carl Schmitt holds political theology as an alternative to nihilism, Jacob Taubes' reading of Pauline messianism shows that liberation must be attained by fighting against the formal order. Taubes thus retains a theological-political lexicon using Eschatology as a synonym of a formal Revolution. Herein lies the reason why he represents the morpho-political reversal of Schmitt's conception of political theology. Walter Benjamin holds the same opinion, indeed, his Theologisch politische Fragment is a morpho-political critique of political theology. The critique of Schmitt's political theories passes through a morphological reconstruction of their premises.

The question at issue here is to find a representative form that is not as authoritarian as the symbolic one. In other words, the political question of representation must recognize the aesthetic problem implied within it. It thus becomes possible to highlight not only that symbolic representation belongs to the past - and is therefore no longer able to represent the contemporary age - but also that it is an authoritarian, violent and mystifying form. Yet, providing a critique of the symbol does not coincide with the refusal of every political representation.

In short, even if a large part of contemporary philosophy seems to stress a catastrophic end to the form of this world, this theoretical frame might not necessarily coincide with an end to every form.

To deconstruct the formal structure of Western power it is no more satisfactory. This power of gestalt-zerstörend - as Taubes defined it - must be complemented by a forming power, like a narrative capable of addressing the alluring side of political theology. Thus, political theology reveals its relevance through its aesthetic declination, being bound to the form as a system of symbolic renewal. Here our focus is on the political form, although this also applies the artistic one. Only by overcoming the idea of a work of art as a shock created just to criticize our contemporaneity, is it possible to change the conception of political form. Art, as well as architecture, sheds light on the existence of radically new forms. Therefore, by reflecting on the relationship between aesthetics and polit- 
ical philosophy we can think about the problem of the re-enactment of narratives, a far more revolutionary engagement.

\section{Bibliography}

Agamben, G. (2007): Il regno e la gloria: Per una genealogia teologica dell'economia e del governo. Vicenza: Neri Pozza.

Assmann, J. (2000): Herrschaft und Heil: Politische Theologie in Altagypten, Israel und Europa. München: Hanser.

Balthasar, H. U. (1961-1969): Herrlichkeit: Eine theologische Ästhetik. Bd. 1. Schau der Gestalt. Einsiedeln: Johannes-Verl.

Balthasar, H. U. (1970): Romano Guardini: Reform aus dem Ursprung. München: Kösel.

Benjamin W. (1920): “Der Begriff der Kunstkritik in der deutschen Romantik”. In:

Schweppenhäuser, H. - Tiedemann, R. (Hg.): Gesammelte Schriften: I,1. Frankfurt am Main: Suhrkamp, 7-122.

Benjamin W. (1921): “Theologisch-politisches Fragment”. In: Schweppenhäuser, H. Tiedemann, R. (Hg.): Gesammelte Schriften, Bd. 2, No. 1. Frankfurt am Main: Suhrkamp, 203-204.

Benjamin W. (1924-1925) “Goethes Wahlverwandtschaflen”. In: Schweppenhäuser, H. Tiedemann, R. (Hg.): Gesammelte Schriften, Bd. 1, No. 1. Frankfurt am Main: Suhrkamp, 123-202.

Benjamin W. (1928): “Ursprung des deutschen Trauerspiels”. In: Schweppenhäuser, H. Tiedemann, R. (Hg.): Gesammelte Schriften, Bd. 1, No. 1. Frankfurt am Main: Suhrkamp, $203-430$.

Benjamin W. (2006): Gesammelte Schriften, Bd. 1, No. 1. Frankfurt am Main: Suhrkamp.

Blumenberg, H. (1973): Die Legitimität der Neuzeit. Frankfurt am Main: Suhrkamp.

Bredekamp, H. (2017): “Walter Benjamin's esteem for Carl Schmitt”. In: Meierhenrich, J. Simons, 0. (Eds.): Oxford Handbook of Carl Schmitt. Corby: Oxford University Press, 679-704.

Bröckling, U. (1993): Katholische Intellektuelle in der Weimarer Republik: Zeitkritik und Gesellschaftstheorie bei Walter Dirks, Romano Guardini, Carl Schmitt, Ernst Michel und Heinrich Mertens. München: Fink.

Bürger, P. (1986): “Carl Schmitt oder die Fundierung der Politik auf Ästhetik”. In: Bürger C. (Hg.): Zerstörung, Rettung des Mythos durch Licht. Frankfurt am Main: Suhrkamp, $170-176$.

Cacciari, M. (2013): Il potere che frena: Saggio di teologia politica. Milano: Adelphi.

Däubler, T. (1916): Hymne an Italien. München: G. Müller.

Esposito, R. (1988): Categorie dell'impolitico. Bologna: Il Mulino.

Esposito, R. (2020a): “Institutional Turn. Carl Schmitt o Santi Romano?”. In: Di Pierro, M. Marchesi, F. - Zaru, E. (eds.): Istituzione: Filosofia, politica, storia. Macerata: Quodlibet, $17-34$.

Esposito, R. (2020b): Pensiero istituente: Tre paradigmi di ontologia politica. Torino: Einaudi. Guardini, R. (1923): Vom Wesen katholischer Weltanschauung. Basel: Hess Verlag.

Levi, N. (2007): “Carl Schmitt and the Question of the Aesthetic". In: New German Critique 101, 27-44. 
Løland, O. J. (2020): Pauline Ugliness: Jacob Taubes and the Turn to Paul. New York: Fordham University Press.

Lönne, K.-E. (1994): “Carl Schmitt und der Katholizismus der Weimarer Republik”. In: Wacker, B. (Hg.): Eigentlich Katholische Verschärfung: Konfession, Theologie Und Politik Im Werk Carl Schmitts. München: Fink, 11-35.

Löwith, K. (1960): “Der okkasionelle Dezisionismus von C. Schmitt” [1935]. In: Löwith, K. (Hg.): Gesammelte Abhandlungen: Zur Kritik der geschichtlichen Existenz. Stuttgart:

Kohlhammer, 93-126.

Marder, M. (2014): Groundless Existence: The Political Ontology of Carl Schmitt. London: Bloomsbury Publishing.

Martin, A. von (1925-1926): “Romantischer 'Katholizismus' und katholische 'Romantik”. In: Hochland 23. No. 1, 315-337.

McCormick, J. P. (2011): Carl Schmitt's Critique of Liberalism. Cambridge: Cambridge University Press.

Pan, D. (2017): “Tragedy as Exception in Carl Schmitt's Hamlet or Hecuba". In: Meierhenrich, J. - Simons, O. (Eds.): Oxford Handbook of Carl Schmitt. New York: Oxford University Press, 731-750.

Peterson, E. (1935): Der Monotheismus als Politisches Problem: Ein Beitrag zur Geischichte der Politischen Theologie im Imperium Romanum. Leipzig: Bei Jakob Hegner.

Roberts, J. (1982): Walter Benjamin. London: Macmillan.

Sander, H.-D. (1970): Marxistische Ideologie und allgemeine Kunsttheorie. Basel: Kyklos-Verlag.

Schlegel, F. - Eichner, H. (1969): Gespräch über die Poesie. Stuttgart: Metzler.

Schmitt, C. (1916): Theodor Däublers Nordlicht: 3 Studien über die Elemente, den Geist u. die Aktualität des Werkes. München: Georg Müller.

Schmitt, C. (1998): Politische Romantik [1919]. Berlin: Duncker und Humblot.

Schmitt, C. (2016): Römischer Katholizismus und politische Form [1923]. Stuttgart: Klett-Cotta.

Schmitt, C. (1956): Hamlet oder Hekuba: Der Einbruch der Zeit in das Spiel. Düsseldorf: Diederichs.

Schmitt, C. - Taubes, J. (2012): Jacob Taubes - Carl Schmitt: Briefwechsel mit Materialien, Hg. von H. Kopp-Oberstebrink, München [u.a.]: Fink.

Stimilli, E. (2019): Teologie e politica: Genealogie e attualità. Macerata: Quodlibet.

Taubes J. (2007): Abendländische Eschatologie [1947]. Berlin: Matthes and Seitz.

Taubes, J. (1982a): “Scholem's Theses on Messianism Reconsidered”. In: Social Science Information 21, 665-675.

Taubes, J. (1982b): “The Price of Messianism”. In: Journal of Jewish Studies 33, 595-600.

Taubes, J. (1986): "Walter Benjamin - ein moderner Marcionit? Scholems Benjamin-Interpretation religionsgeschichtlich überprüft”. In: Bolz, N. W. - Faber R. (Hg.): Antike und Moderne. Zu Walter Benjamins "Passagen”. Würzburg: Verlag Königshäusern \& Neumann, 286-298.

Taubes, J. (1993): Die politische Theologie des Paulus: Vorträge, gehalten an der Forschungsstätte der Evangelischen Studiengemeinschaft in Heidelberg, 23. 27. Februar 1987. München: Fink.

Vercellone, F. (1998): Nature del tempo: Novalis e la forma poetica del romanticismo tedesco. Milano: Guerini. 